\title{
42. GREEN SPHERULES AS INDICATORS OF THE CRETACEOUS/TERTIARY BOUNDARY IN DEEP SEA DRILLING PROJECT HOLE 603B ${ }^{1}$
}

\author{
Gerard T. Klaver, Theo M. G. van Kempen, Frans R. Bianchi, Geological Institute, University of Amsterdam \\ and \\ Sjerry J. van der Gaast, Netherlands Institute for Sea Research ${ }^{2}$
}

\begin{abstract}
Dark green spherules occur in the lower part of a turbidite in Section 603B-22-3, at the $70 \mathrm{~cm}$ level. In all probability these spherules originally consisted of massive glass, but now appear to have become completely altered into smectite. The presence of numerous microscopic fissures in the spherules probably mediated in the alteration process.

Judging by the presence of similar spherules at the Cretaceous/Tertiary $(\mathrm{K} / \mathrm{T})$ boundary in DSDP Hole $390 \mathrm{~B}$, the green spherules are thought to represent diagenetically altered impact ejecta from one large or several smaller extraterrestrial objects at the end of the Cretaceous. The presence of anomalously high concentrations of $\mathrm{Ni}, \mathrm{Co}$, and $\mathrm{As} \mathrm{higher}$ up in the turbidite are in agreement with an expected enrichment of these elements in the K/T boundary clay. However, precise Ir analyses are necessary in order to confirm this.
\end{abstract}

\section{INTRODUCTION}

Hole 603B was the deepest of four holes drilled at Site 603 on the lower continental rise in the western North Atlantic Ocean, off North Carolina. Coring at this hole recovered a Lower Cretaceous to lower Pleistocene sedimentary section, with an overall recovery of approximately $70 \%$. Core 603B-22 includes the lowermost portion of lithostratigraphic Unit II and the uppermost portion of Unit III (Site 603 chapter, this volume). Unit III consists of $96 \mathrm{~m}$ of variegated claystones (Fig. 1), and the upper half of this lithologic unit is barren of both microfossils and pollen. Section 603B-22-3 contains intriguing dark green spherules that were sampled for this study. The age of these spherules is subject to question because of the lack of fossils in this section, but the ages of the overlying and underlying sediments indicate that the upper part of lithologic Unit III can range from Coniacian-Campanian to early Paleocene in age (Site 603 chapter, this volume). Normal remanent magnetic intensities were determined for 10 samples of Cores 603-18 to -22 but proved too low in this section to establish a reliable magnetostratigraphy (see Appendix), so no further age information can be provided by the magnetostratigraphy of these sediments.

Section 603B-22-3 consists of clayey, silty sandstone which is grayish blue green $(5 \mathrm{BG} 5 / 2)$ at the top and darkens to $5 \mathrm{BG} 4 / 2$ in the lower part of a turbidite at 70 $\mathrm{cm}$ (Site 603 chapter, this volume). The interval from $67-72 \mathrm{~cm}$ shows small-scale cross bedding and a coarser, sand-sized basal layer of grains ranging in diameter from 0.5-1 mm (Plate 1). Dark green spherules, which are light grayish green when dry, are found only in this par-

\footnotetext{
${ }^{1}$ van Hinte, J. E., Wise, S. W., Jr., et al., Init. Repts. DSDP, 93: Washington (U.S. Govt. Printing Office).

2 Present addresses: (Klaver, van Kempen, Bianchi) Institute voor Aardwetenschappen, Vrije Universiteit, P.O. Box 7161, 1007 Mc Amsterdam, The Netherlands; (van der Gaast) Netherlands Institute for Sea Research, P.O. Box 59, Texel, The Netherlands.
}

ticular interval, which is almost completely made up of spherules, both intact and broken. The laminations of the cross bedding are delineated by complete spherules. Below this cross-bedded interval, the core is dark reddish brown with irregular bands and mottles of greenish clayey, silty sandstone. The morphology, petrography, mineralogy, and chemistry of these dark green spherules are reported here and correlated with similar spherules found at the Cretaceous/Tertiary $(\mathrm{K} / \mathrm{T})$ boundary in DSDP Hole 390A (J. Smit, pers. comm., 1984).

\section{METHODS}

Spherules from the bulk sample taken from the complete interval (67-72 cm, Plate I) were handpicked under a stereomicroscope with a dry brush; this was done because when the spherules come in contact with water they quickly swell and then disintegrate completely. Representative handpicked spherules were selected for study using the scanning electron microscope (SEM) and the electron microprobe. For the SEM a large number of complete spherules were broken, so that their internal structure could be studied.

The electron microprobe analyses of three polished thin sections containing 18 spherules in total were carried out with a Cambridge Microscan, Mark 9. All analyses are raster analyses, and intensities of natural silicates and oxides have been applied for reference.

$\mathrm{X}$-ray powder diffraction (XRD) analyses were made on powdered, orientated, and bulk samples. Orientated samples were obtained by suctioning $\mathrm{Ca}$-exchanged suspensions of milled spherules onto polished ceramic tiles. The orientated samples thus obtained were scanned at $0 \%, 50 \%$, and $100 \%$ relative humidity. In order to get precise $\AA$ values and to compare the peak intensities in the various diagrams, $\mathrm{MoS}_{2}\left(16.7^{\circ} 2 \theta\right.$ Cobalt $\left.\mathrm{K} \alpha\right)$ was used as an internal standard. Bulk samples were milled and then scanned at $50 \%$ relative humidity. XRD analyses were carried out using a Philips PW 1730 generator, channel control PW 1390, motor control PW 1394, and a goniometer PW $1050 / 25$ equipped with a curved graphite monochromator and a helium-vacuum attachment as described by van der Gaast and Vaars (1981). For the orientated samples the goniometer was extended with a computer-steered divergence slit system that made possible a constant, radiated sample area independent of the angle of incidence. The goniometer was used in stepscan mode $\left(4 \mathrm{~s} 0.02^{\circ-1}\right)$ from 2 to $17.5^{\circ} 2 \theta$. For the bulk samples the divergence slit was fixed at $1^{\circ}$; a receiving slit of $0.2 \mathrm{~mm}$ and an antiscatter slit of $1^{\circ}$ were used. In this case the goniometer speed was $1^{\circ} 2 \theta . \mathrm{min}^{-1}$ from 3 to $80^{\circ} 2 \theta$.

Bulk samples were taken from Section 603B-22-3, at 51-52, 66-67, $70-71,71-72,73-74$, and $76-77 \mathrm{~cm}$ and analyzed by the routine instru- 


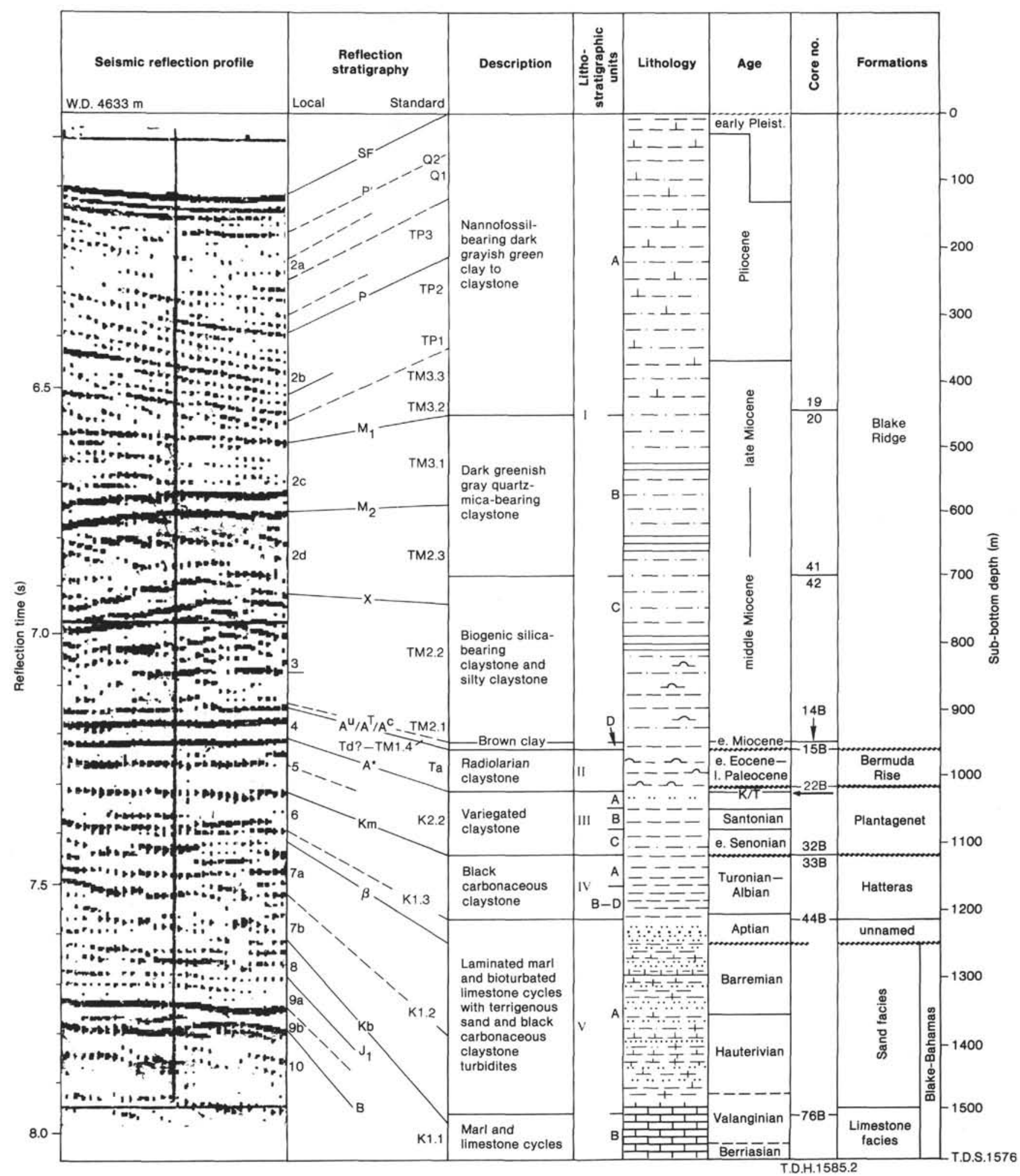

Figure 1. Stratigraphic summary of Site 603 (Holes 603A, 603B, 603C). Units I-IV are local lithostratigraphic units (see Site 603 chapter, this volume). Arrow points to Core 603B-22, in which the interval with the dark green spherules occurs, $1.55 \mathrm{~m}$ below the boundary between Units II and III $\left(=\mathrm{A}^{*}\right)$. Because only $6.36 \mathrm{~m}$ of the $9.0 \mathrm{~m}$ cored was recovered, the K/T boundary could be as much as $4.19 \mathrm{~m}$ below the Unit II/III boundary. 
mental neutron activation analysis (INAA) method (de Bruin, 1983) in use at the IRI (Interuniversity Reactor Institute) in Delft.

\section{RESULTS}

\section{External and Internal Texture of the Spherules}

A stereophoto of randomly selected spherules (Plate 2, Fig. 1) shows generally perfect spheres up to $2 \mathrm{~mm}$ across, with a few drop-shaped spheroids. The surface of the spherules is smooth and glossy (Plate 2, Figs. 1 and 2), but occasionally a nodular surface is encountered (Plate 2, Fig. 3). The spherules are massive (Plate 3, Fig. 2), hollow (Plate 3, Fig.3), or composite (e.g., Plate 3, Fig. 4; Plates 4, 6, 8, and 9, Fig. 1). The composite type contains several randomly spaced, massive, globular bodies enclosed within a fine crystalline matrix, which forms the bulk of the mass (Plate 4). SEM micrographs were made of the fractured surfaces of the opposing halves of a cross-sectioned spherule with an in situ globule (Plate 4, Fig. 1) and its mold (Plate 4, Fig. 2 ). The surface of this particular globule shows a peculiar band formed of a series of fusiform impressions in juxtaposition, which correspond in detail with the opposite positive relief at the inside of the mold (Plate 4, Figs. 3, and 4). Higher-resolution micrographs of the groundmass (Plate 5, Figs. 1 and 2) revealed no deformation structures at or around the edges of the fusiform impressions. Examination of some 200 globules revealed no similar patterns of surficial impressions. In Plate 5, Figs. 3 and 4, another example of a composite type of spherule is given, cut in half in order to examine the internal globules and their corresponding molds.

Micrographs of thin sections of spherules are presented in Plates 6, 7,8, and 9. Most spherules, when viewed in transmitted light, appear to house a variable number of differently sized, massively filled, and randomly spaced circular bodies with a smooth surface. These bodies are indentical to the globules within the composite type of spherules on SEM micrographs (Plates 4 and 5). In transmitted light, spherules often show the presence of a comparatively dense "wall," varying considerably in width (see Plates 6-9) from place to place within the same spherule. These walls show a conspicuous and characteristic crenulate inner boundary, which has resulted from the formation of many radially grown, irregularly coalesced nodules. These nodules apparently arose from an influx of material that penetrated via narrow surficial fractures (arrows in Plates 6, 7, 8, and 9). Fissures similar to those that mediated in the production of the "walls" of the spherules are directed toward the globular bodies located both within the "walls" and farther into the interior of a spherule (e.g., Plate 6, Fig. 2; Plate 9, Fig. 1). Apparently, these fissures functioned as feeder channels for material that yielded the globules. A dark substance, rich in finely distributed iron that could not be incorporated into the smectite, borders both the irregular, crenulate, inner boundary of the nodular "wall" and the smooth outer skin of the circular (globular) bodies.

\section{X-Ray Diffraction}

The XRD scans on orientated samples at different relative humidities are given in Figure 2 . The $\AA$ values

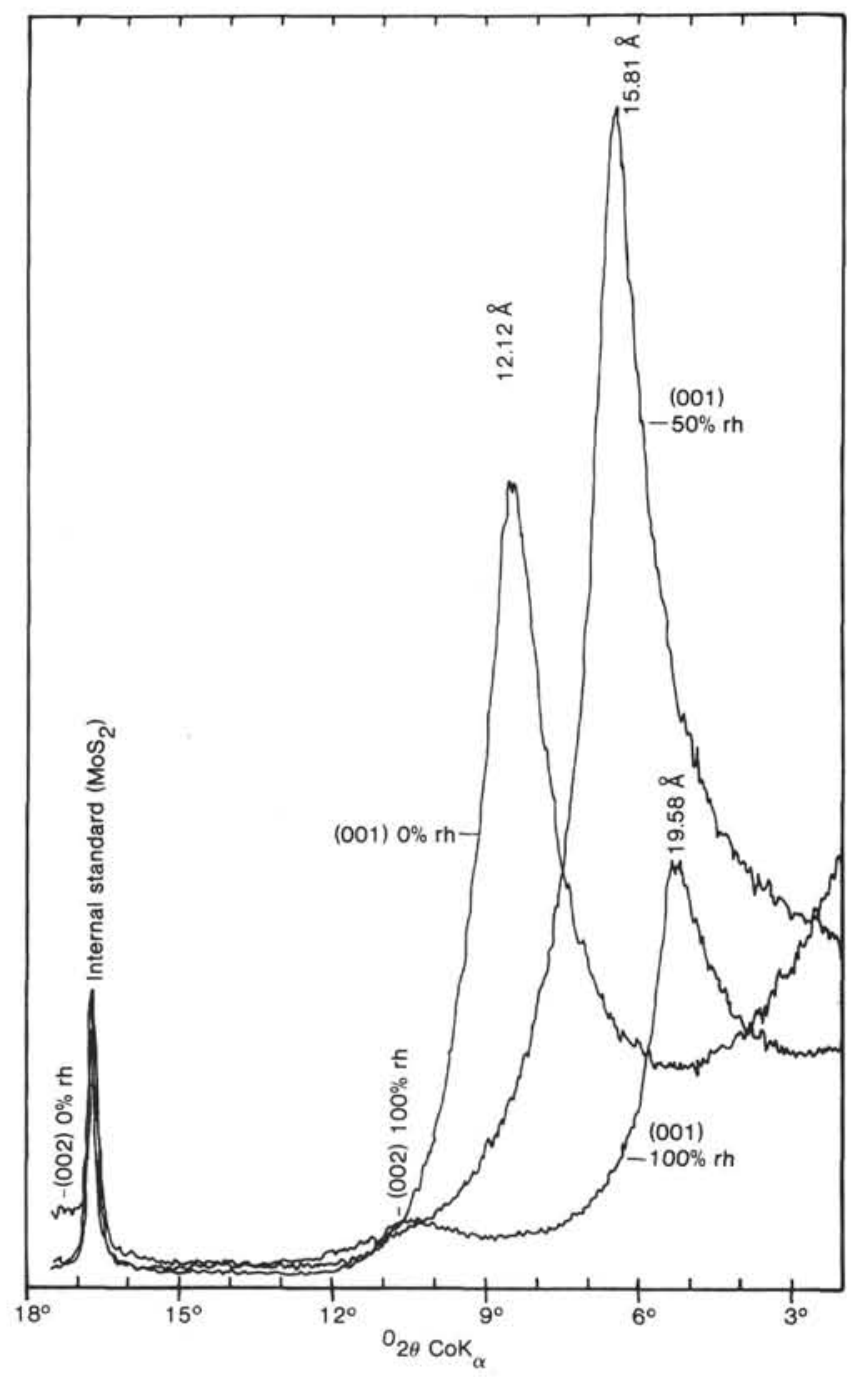

Figure 2. XRD scans on orientated samples of the dark green spherules, showing shift in 001 reflections at different relative humidities (rh). The shift in 001 reflections is characteristic for smectite.

obtained for the 001 reflections and the corresponding widths of the peaks in these scans indicate that the spherules are completely constituted of moderately crystalline smectite. In the bulk scan only smectite reflections are found, except for a small quartz peak at $31.07^{\circ} 2 \theta$, whose height indicates the presence of less than 1 vol. $\%$ quartz. The occurrence of a reflection at $73.20^{\circ}(1.500$ A) in the bulk scan points to a dioctahedral smectite.

\section{Microprobe Results}

Figure 3 shows the locations of the microprobe raster analyses within the spherules; spherule 5 in this figure corresponds with that illustrated in Plate 7. The analyses are given in Table 1 and the mineral compositions are calculated on the basis of 22 oxygens. Table 1 shows that the dense "walls" of the spherules, the globules within the "walls," and the globules in the interior of the spherules all have a similar composition. From the microprobe and XRD results we conclude that the smectite from the spherules is an Fe-rich dioctahedral smectite. The smectite differs from published analyses of other 

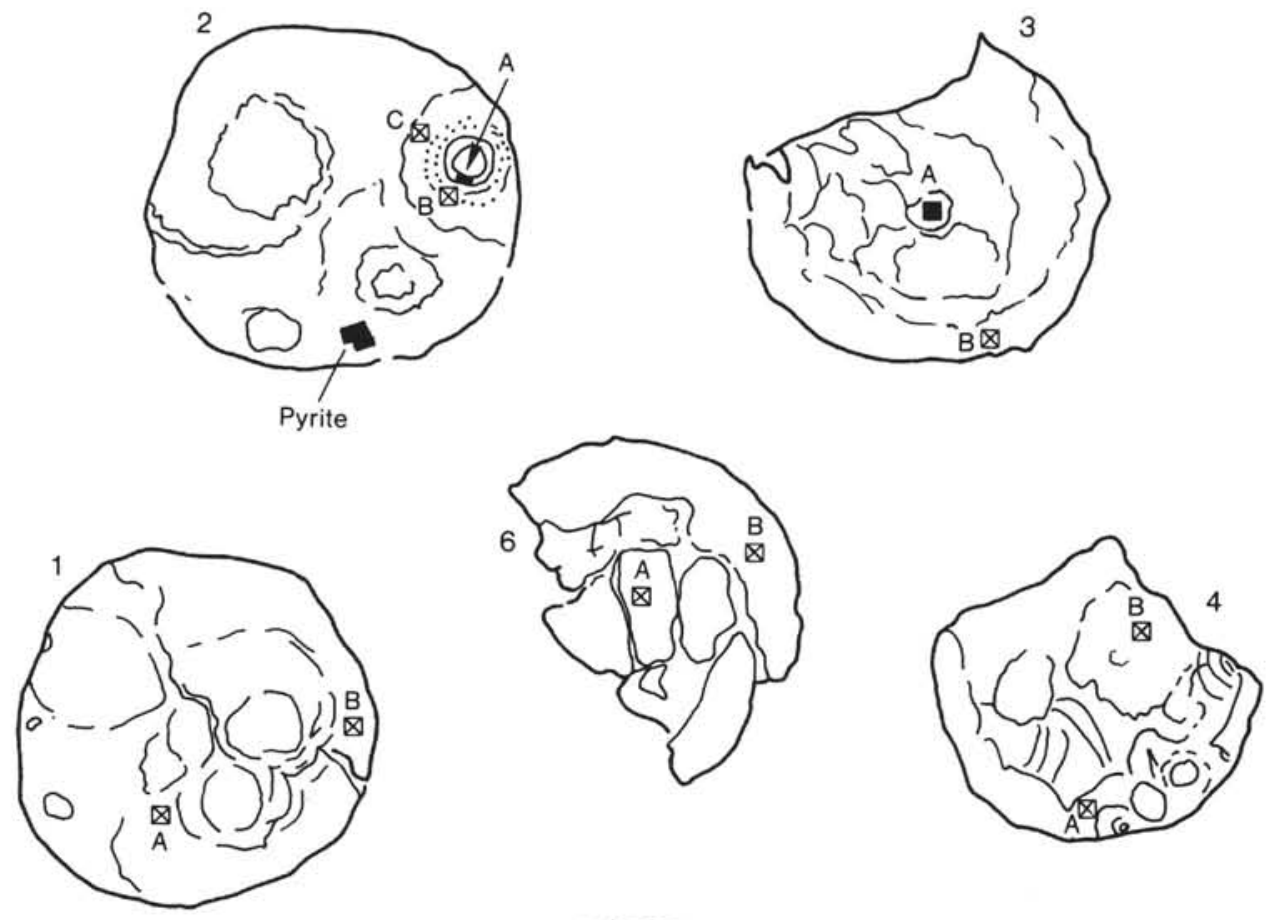

Figure 3. Outline drawings of green spherules, showing the locations of the electron microprobe raster analyses (Table 1). Spherule No. 5 is shown in Plate 7, Figs. 1 and 2.

Table 1. Microprobe analyses of montmorillonite from Sample 603B-22-3, 66-72 cm. ${ }^{\mathrm{a}}$

\begin{tabular}{|c|c|c|c|c|c|c|c|c|c|c|c|c|c|}
\hline & $1 \mathrm{~A}$ & 1B & $2 \mathrm{~A}$ & $2 \mathrm{~B}$ & $3 \mathrm{~A}$ & 3B & $4 \mathrm{~A}$ & 4B & $5 \mathrm{~A}$ & SB & $5 C$ & $6 \mathrm{~A}$ & $6 \mathrm{~B}$ \\
\hline $\mathrm{SiO}^{2}$ & 52.4 & 51.9 & 59.3 & 55.3 & 55.6 & 54.3 & 54.0 & 54.8 & 56.0 & 56.1 & 53.3 & 55.1 & 54.7 \\
\hline $\mathrm{Al}^{2} \mathrm{O}^{3}$ & 18.3 & 18.0 & 17.2 & 19.4 & 19.8 & 18.8 & 17.7 & 19.1 & 20.9 & 20.4 & 19.0 & 17.2 & 17.5 \\
\hline $\mathrm{TiO}^{2}$ & 0.32 & 0.29 & 0.15 & 0.40 & 0.32 & 0.46 & 0.45 & 0.32 & 0.31 & 0.36 & 0.46 & 0.46 & 0.55 \\
\hline $\mathrm{FeO}$ & 10.2 & 9.34 & 8.77 & 10.8 & 10.0 & 11.0 & 10.8 & 10.6 & 9.44 & 10.1 & 9.32 & 12.0 & 11.0 \\
\hline $\mathrm{MnO}$ & 0.08 & 0.09 & 0.23 & 0.14 & 0.14 & 0.10 & 0.08 & 0.08 & 0.14 & 0.08 & 0.14 & 0.09 & 0.08 \\
\hline $\mathrm{MgO}$ & 2.63 & 2.72 & 2.82 & 2.71 & 2.80 & 2.67 & 2.81 & 2.63 & 2.54 & 2.64 & 2.35 & 2.92 & 2.94 \\
\hline $\mathrm{CaO}$ & 0.34 & 0.23 & 0.16 & 0.27 & 0.31 & 0.27 & 0.27 & 0.30 & 0.30 & 0.33 & 0.30 & 0.25 & 0.28 \\
\hline $\mathrm{Na}^{2} \mathrm{O}$ & 0.99 & 0.69 & 1.26 & 1.34 & 1.38 & 1.06 & 1.10 & 1.44 & 1.42 & 1.52 & 1.03 & 1.18 & 0.99 \\
\hline $\mathrm{K}^{2} \mathrm{O}$ & 2.63 & 2.50 & 0.37 & 2.83 & 2.39 & 2.79 & 2.71 & 2.83 & 2.16 & 2.46 & 1.74 & 3.25 & 2.49 \\
\hline Total \% & 87.89 & 85.76 & 90.26 & 93.19 & 92.74 & 91.35 & 89.92 & 92.10 & 93.31 & 93.99 & 87.64 & 92.45 & 90.53 \\
\hline \multicolumn{14}{|c|}{ Number of cations on basis of 22 oxygens } \\
\hline $\mathrm{Si}$ & 7.53 & 7.5 & 8 & 7.5 & 7. & 7. & 7.6 & 7.5 & 7. & 7.50 & 7. & 7.61 & 7.63 \\
\hline Al & 3.10 & 3.11 & 2.74 & 3.10 & 3.15 & 3.07 & 2.93 & 3.10 & 3.29 & 3.21 & 3.18 & 2.80 & 2.88 \\
\hline $\mathrm{Ti}$ & 0.035 & 0.031 & 0.016 & 0.041 & 0.033 & 0.048 & 0.048 & 0.033 & 0.031 & 0.036 & 0.049 & 0.047 & 0.058 \\
\hline $\mathrm{Fe}^{2+}$ & 1.22 & 1.14 & 0.992 & 1.23 & 1.13 & 1.28 & 1.28 & 1.21 & 1.06 & 1.13 & 1.11 & 1.39 & 1.28 \\
\hline $\mathrm{Mn}$ & 0.010 & 0.012 & 0.026 & 0.016 & 0.016 & 0.011 & 0.010 & 0.009 & 0.015 & 0.009 & 0.016 & 0.011 & 0.010 \\
\hline $\mathrm{Mg}$ & 0.564 & 0.593 & 0.568 & 0.549 & 0.566 & 0.551 & 0.590 & 0.537 & 0.507 & 0.526 & 0.499 & 0.602 & 0.610 \\
\hline $\mathrm{Ca}$ & 0.052 & 0.035 & 0.023 & 0.039 & 0.045 & 0.040 & 0.041 & 0.044 & 0.043 & 0.047 & 0.045 & 0.038 & 0.042 \\
\hline $\mathrm{Na}$ & 0.276 & 0.196 & 0.33 & 0.354 & 0.362 & 0.284 & 0.300 & 0.384 & 0.3 & 0.394 & 0.2 & 0.317 & 0.269 \\
\hline K & 0.483 & 0.466 & 0.06 & 0.4 & 0.413 & 0.493 & 0.487 & 0.496 & 0.370 & 0.420 & 0.316 & 0.574 & 0.443 \\
\hline Total & 13.270 & 13.163 & 12.790 & 13.330 & 13.245 & 13.297 & 13.286 & 13.333 & 13.184 & 13.272 & 13.080 & 13.389 & 13.222 \\
\hline
\end{tabular}

${ }^{\text {a }}$ All samples examined (1A, 1B, etc.) were $7 \times 9 \mu \mathrm{m}$ except for Sample $2 \mathrm{~A}$, which was $4 \times 5 \mu \mathrm{m}$. Locations of analyses shown in Figure 3 . 
types (Weaver and Pollard, 1973) in having a much higher $\mathrm{K}_{2} 0$ content.

\section{INAA Results}

The INAA analyses yield data on the following elements: $\mathrm{Na}, \mathrm{K}, \mathrm{Ca}, \mathrm{Sc}, \mathrm{Cr}, \mathrm{Fe}, \mathrm{Co}, \mathrm{Ni}, \mathrm{Cu}, \mathrm{Zn}, \mathrm{As}, \mathrm{Br}$, $\mathrm{Rb}, \mathrm{Sr}, \mathrm{Zn}, \mathrm{Sb}, \mathrm{Cs}, \mathrm{Ba}, \mathrm{La}, \mathrm{Ce}, \mathrm{Sm}, \mathrm{Eu}, \mathrm{Tb}, \mathrm{Yb}, \mathrm{Lu}$, $\mathrm{Hf}, \mathrm{Ta}, \mathrm{Th}$, and $\mathrm{U}$. The precision of the determinations is better than $10 \%(1 \sigma)$ except for $\mathrm{Ta}$ and $\mathrm{Zr}(20 \%, 1 \sigma)$. No correction has been applied for carbonate content, as the INAA analyses give a detection limit for $\mathrm{Ca}(<$ $2 \%$ ). Table 2 summarizes the data and Figure 4 shows the profiles of $\mathrm{Th}, \mathrm{Rb}, \mathrm{La}, \mathrm{Sm}, \mathrm{Yb}, \mathrm{Hf}, \mathrm{Zr}, \mathrm{Fe}, \mathrm{Cr}, \mathrm{Co}$, $\mathrm{Ni}, \mathrm{As}, \mathrm{Sb}$, and $\mathrm{U}$.

$\mathrm{Rb}, \mathrm{La}, \mathrm{Sm}$, and $\mathrm{Yb}$ have very similar profiles; these elements are depleted not only in the interval with the spherules (S-interval) but also in the interval just above it. The mean Rare Earth Element (REE) abundances in shales have been interpreted as representing the concentration of the REE in the continental crust (e.g., Piper, 1974; Haskin and Paster, 1979; McLennan et al., 1980), which is also the source of the sediments analyzed here. The distribution of the REE in the samples analyzed can therefore be seen best in shale-normalized REE diagrams (Piper, 1974). Figure 5 shows that samples from section 603B-22-3 at 51-52, 73-74, and 76-77 cm have similar REE abundances compared to shales, with slight enrichments in $\mathrm{La}, \mathrm{Ce}, \mathrm{Sm}$, and Eu. The other three samples $(66-67,70-71$, and 71-72 cm) have similar patterns but significantly lower abundances. In these samples Eu is more depleted than the other REEs (Fig. 5).

Th shows a peak in the basal part of the S-interval. $\mathrm{Hf}$ and $\mathrm{Zr}$ are roughly constant in the samples analyzed,

Table 2. INAA results for samples from Section 603B-22-3.

\begin{tabular}{|c|c|c|c|c|c|c|}
\hline & $51-52^{a}$ & $66-67$ & $70-71$ & $71-72$ & $73-74$ & $76-77$ \\
\hline $\mathrm{Na}$ & 0.76 & 1.06 & 1.15 & 0.94 & 0.89 & 0.75 \\
\hline K & 2.55 & 1.86 & 1.67 & 1.59 & 2.39 & 2.36 \\
\hline $\mathrm{Sc}$ & 3 & 19 & 18 & 14 & 17 & 16 \\
\hline $\mathrm{Cr}$ & 120 & 103 & 73 & 63 & 138 & 121 \\
\hline $\mathrm{Fe}$ & 2.77 & 4.25 & 4.08 & 3.09 & 4.09 & 5.64 \\
\hline Co & 14 & 323 & 33 & 26 & 73 & 20 \\
\hline $\mathrm{Ni}$ & 22 & 316 & 101 & 78 & 121 & 58 \\
\hline $\mathrm{Cu}$ & 43 & 97 & 234 & 68 & 131 & 122 \\
\hline $\mathrm{Zn}$ & 104 & 160 & 148 & 108 & 139 & 107 \\
\hline As & 3 & 25 & 13 & 10 & 5 & 10 \\
\hline $\mathrm{Br}$ & 8 & 10 & 17 & 9 & 5 & 6 \\
\hline $\mathrm{Rb}$ & 126 & 92 & 83 & 69 & 125 & 125 \\
\hline $\mathrm{Sr}$ & 136 & 230 & 220 & 160 & 157 & 200 \\
\hline $\mathrm{Zn}$ & 580 & 294 & 414 & 683 & 321 & 325 \\
\hline Sb & 0.3 & 0.9 & 0.9 & 0.6 & 0.9 & 1.2 \\
\hline Cs & 6.3 & 4.7 & 2.9 & 2.9 & 7.6 & 6.8 \\
\hline $\mathrm{Ba}$ & 350 & 220 & 127 & 275 & 330 & 280 \\
\hline $\mathrm{La}$ & 49.2 & 34.5 & 25.6 & 35.0 & 43.4 & 47.8 \\
\hline $\mathrm{Ce}$ & 99 & 63 & 52 & 65 & 86 & 98 \\
\hline Sm & 8.95 & 6.51 & 4.87 & 5.92 & 9.28 & 10.90 \\
\hline Eu & 1.91 & 1.08 & 0.76 & 0.82 & 1.60 & 1.94 \\
\hline $\mathrm{Tb}$ & 1.32 & 0.98 & 0.79 & 0.96 & 1.11 & 1.17 \\
\hline $\mathrm{Yb}$ & 3.45 & 2.40 & 1.95 & 2.86 & 3.22 & 3.18 \\
\hline $\mathrm{Lu}$ & 0.61 & 0.49 & 0.41 & 0.58 & 0.61 & 0.57 \\
\hline $\mathrm{Hf}$ & 12.5 & 8.7 & 11.0 & 16.9 & 8.3 & 7.8 \\
\hline $\mathrm{Ta}$ & 1.20 & 0.95 & 1.35 & 1.07 & 1.89 & 1.15 \\
\hline Th & 14.40 & 11.40 & 11.60 & 14.10 & 13.60 & 13.50 \\
\hline $\mathrm{U}$ & 5.29 & 5.23 & 2.85 & 5.30 & 2.45 & 2.08 \\
\hline $\mathrm{Hf} / \mathrm{Lu}$ & 20 & 18 & 27 & 29 & 14 & 14 \\
\hline
\end{tabular}

Note: Concentrations in ppm, except for $\mathrm{Na}, \mathrm{K}$, and $\mathrm{Fe}(\%)$.

a Sample interval, in $\mathrm{cm}$. but again only the basal part of the S-interval is highly enriched. It has recently been shown that turbidites have significantly higher amounts of $\mathrm{Hf}$ and $\mathrm{Zr}$ than the pelagic sediments in which they are intercalated (Patchett et al., 1984; van Weering and Klaver, 1985). In clastic sediments the elements $\mathrm{Hf}$ and $\mathrm{Zr}$ are concentrated mainly in zircon minerals. Zircon grains are very resistant to weathering and therefore easily transported by turbidites toward the deep ocean. Sorting in turbidity currents results in the preferential concentration of zircon in the coarser fractions (van Weering and Klaver, 1985). As expected because of the sorting of the mineral zircon, the $\mathrm{Zr}$ and $\mathrm{Hf}$ peaks are found in the basal part of the S-interval and not in the remainder of the turbidite.

$\mathrm{Fe}, \mathrm{Cr}$, and $\mathrm{Sb}$ again show similar profiles whereas $\mathrm{U}$ shows just the opposite pattern. The sediments above the S-interval are grayish to dark blue green, whereas those below it are reddish brown. From the Fe profile it can be inferred that the reddish color in the sediments below the S-interval is due to a higher $\mathrm{Fe}$ content. In contrast, the concentration of $U$ is significantly higher in the blue green sediments than in the reddish ones. The change in color at the S-interval and the $\mathrm{Fe}$ and $\mathrm{U}$ profiles indicate that, during deposition of the sediments below the S-interval, bottom waters were more oxygenated than during the deposition of the sediments above it (Dean and Gardner, 1982).

Perhaps the most striking feature of the elemental profiles across this section is the enrichment in $\mathrm{Ni}, \mathrm{Co}$, and As (respectively $4.2 \times, 9.7 \times, 3.0 \times$ ) in the sample just above the S-interval. This enrichment is not easy to explain. Enrichment of these elements has been reported from Cretaceous black shales (Brumsack, 1980) and is also present in recent sapropels of the eastern Mediterranean (Klaver, unpubl. data). On the other hand, $\mathrm{Ni}$, $\mathrm{Co}$, and As are also frequently enriched in the $\mathrm{K} / \mathrm{T}$ boundary clay (Smit and Ten Kate, 1982). Black shales and sapropels are deposited under anoxic conditions and contain high percentages of organic carbon. Furthermore, they not only are enriched in $\mathrm{Ni}, \mathrm{Co}$, and $\mathrm{As}$, but also in $\mathrm{Br}$ (which always correlates perfectly with the percentage of organic carbon; Klaver, unpubl. data), Sb, $\mathrm{U}$, and Se. The absence of enrichment in the latter elements and in organic carbon indicates that reducing conditions are not a likely explanation for the enrichment of $\mathrm{Ni}, \mathrm{Co}$, and As in this sample.

\section{DISCUSSION AND CONCLUSIONS}

The XRD analyses show that only traces of quartz occur within the spherules. In the sediments above and below the S-interval and in the matrix of the latter, quartz is abundantly present. Consequently, the spherules cannot be regarded as concretions formed in the sediments. Moreover, the major element composition of the smectite differs significantly from that of diagenetic nonmarine and diagenetic and hydrothermal marine smectites (Kastner et al., 1984; Weaver and Pollard, 1973).

Clearly, another explanation for the presence and the origin of the spherules must be found. Jan Smit (pers. comm., 1984) found identical spherules at precisely the $\mathrm{K} / \mathrm{T}$ boundary in DSDP Hole 390B, located on the Blake Plateau (Fig. 6). Here the presence of abundant micro- 


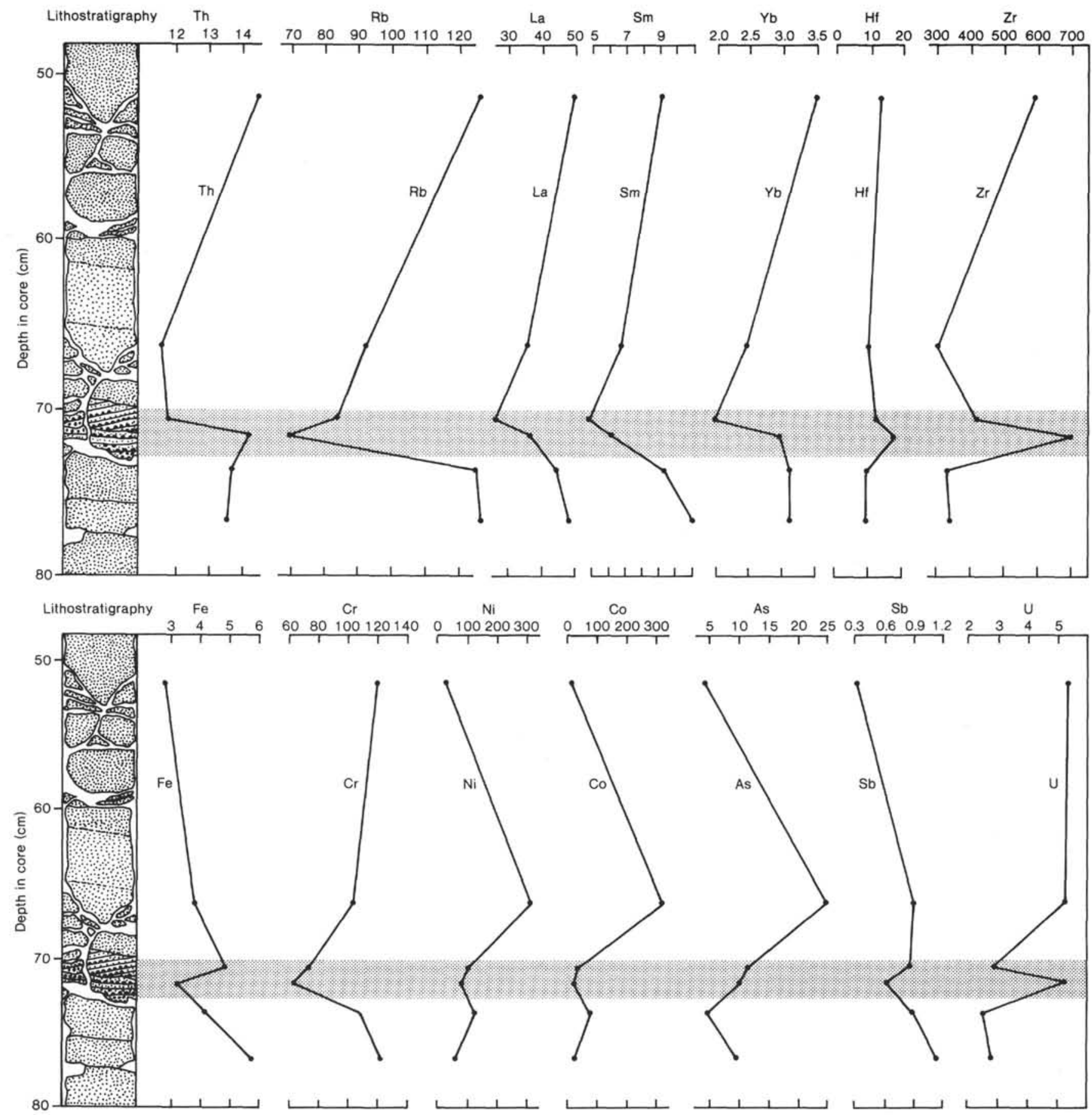

Figure 4. Concentration profiles for Th, $\mathrm{Rb}, \mathrm{La}, \mathrm{Sm}, \mathrm{Yb}, \mathrm{Hf}, \mathrm{Zr}, \mathrm{Fe}, \mathrm{Cr}, \mathrm{Ni}, \mathrm{Co}, \mathrm{As}, \mathrm{Sb}$, and $\mathrm{U}$ across the interval with dark green spherules (Sinterval, shaded band) in 603B-22-3, 48-80 cm. All values are ppm except for Fe, which is in \%. Note the depletion of the REE (La, Sm, Yb) and $\mathrm{Rb}$ in the interval with the green spherules and the sample above it, and the enrichment of the latter sample in Ni, Co, and As. See text for explanation.

fossils made it possible to locate the Cretaceous/Tertiary boundary (Schmidt, 1978). If the spherules in both intervals are from the same event, the spherules of the Slayer are of Cretaceous/Tertiary boundary age, which is compatible with the ages obtained from above and below core 603B-22 (Fig. 1).

At present, the impact of a large extraterrestrial object (or several smaller objects) is widely accepted as the most plausible explanation for the worldwide iridium anomaly at the end of the Cretaceous (e.g., Alvarez et al., 1980; Smit and Hertogen, 1980). The recent report of shocked quartz grains (possibly stishovite) in the $\mathrm{K} / \mathrm{T}$ boundary clay of Montana (Bohor et al., 1984) provides independent and even more definite proof of a meteorite impact at the $\mathrm{K} / \mathrm{T}$ boundary. In addition to this evidence, smectite spherules (Kastner et al., 1984; J. Smit, unpublished results for DSDP Hole 390B), sanidine (Smit and Klaver, 1981), and spherules bearing iron-alumino- 


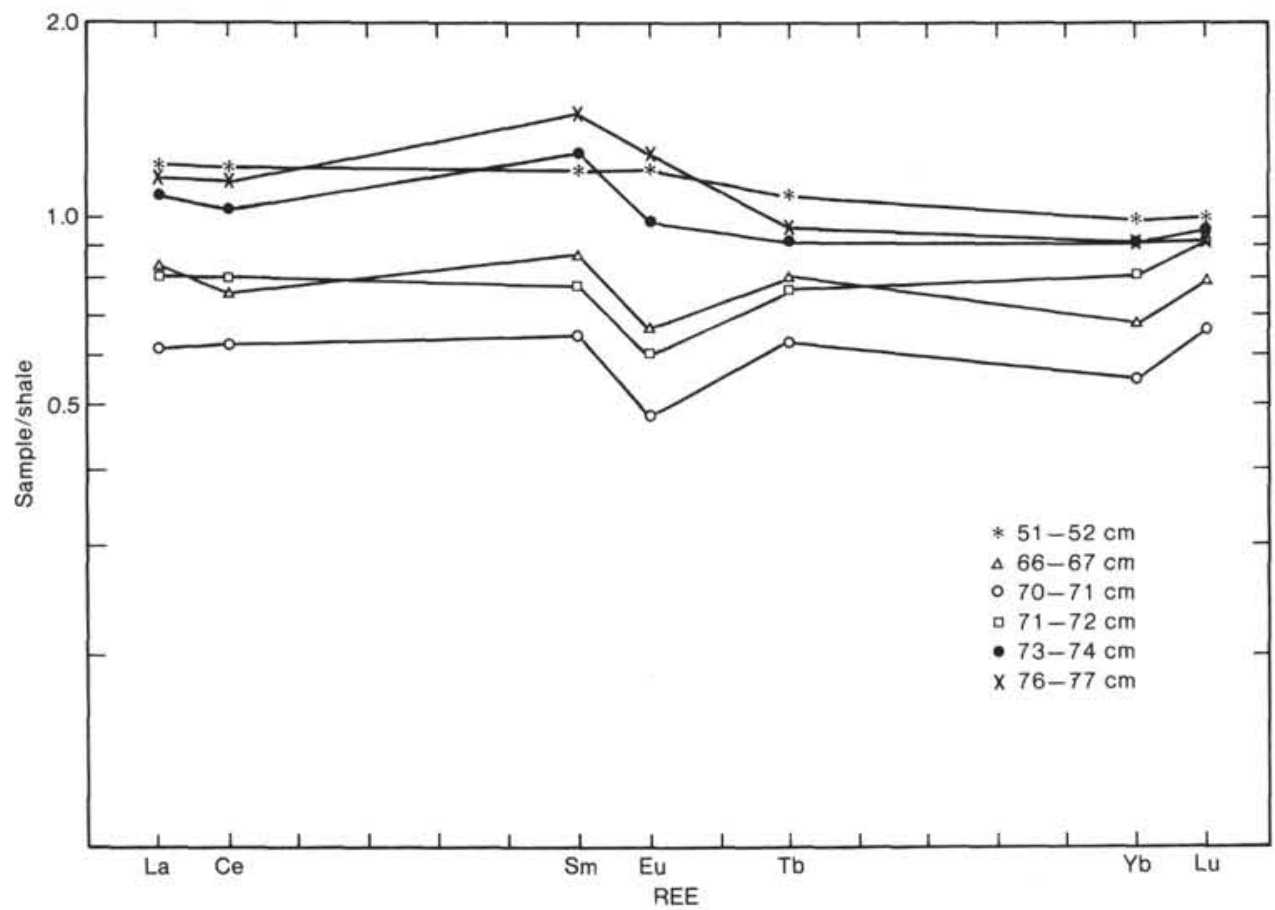

Figure 5. Shale-normalized REE diagrams for samples from Section 603B-22-3. Note depletion in total REE in samples from the interval with the dark green spherules and in the sample above it (samples at $66-67,70-71$, and $71-72 \mathrm{~cm}$ ), and the presence of a negative Eu anomaly in these samples.

silicate (Montanari et al., 1983) and spinel (Smit and Kyte, 1984) have been found. These spherules are regarded as cosmogenic and impact ejecta (microtektites), completely altered through diagenesis after deposition. Associated with an Ir anomaly, the spherules are also distributed worldwide at the K/T boundary (Smit, 1984).

This correlation of the green smectite spherules with the $\mathrm{K} / \mathrm{T}$ boundary spherules found in DSDP Hole 390B is supported by other evidence. Not only is Ir enriched in the $\mathrm{K} / \mathrm{T}$ boundary clay, but also $\mathrm{Ni}, \mathrm{Co}, \mathrm{As}$, and $\mathrm{Sb}$, whereas the REE are strongly depleted (e.g., Smit and Ten Kate, 1982). Figure 4 shows that $\mathrm{Ni}, \mathrm{Co}$, and As are strongly enriched in the sample from just above the Sinterval. The REE are depleted in both the latter sample and in the two samples of the S-interval. The depletion in the REE and enrichment of $\mathrm{Ni}, \mathrm{Co}$, and $\mathrm{As}$ in the sample from just above the S-interval need further explanation. The presence of parallel laminations, cross bedding, and enrichment of $\mathrm{Hf}$ and $\mathrm{Zr}$ in the basal part of the S-interval indicates that the spherules were transported by a turbidite. This turbidite has sorted out the original $\mathrm{K} / \mathrm{T}$ boundary clay, resulting in concentration of the dark green spherules in the parallel-laminated and cross-bedded bottom part, whereas high concentrations of $\mathrm{Ni}, \mathrm{Co}$, and As, and possibly Ir, reside in the silty claystones above this section.

The Hf/Lu ratio of the sample from just above the Sinterval is greater than 10 (Table 2), which indicates that it is part of a fine-grained turbidite (pelagic sediments have $\mathrm{Hf} / \mathrm{Lu}$ ratios significantly lower than 10; Klaver, unpubl. data). The routine INAA method used here has an iridium detection limit of about $60 \mathrm{ppb}$. Since published results on the $\mathrm{K} / \mathrm{T}$ boundary clay show that in general the iridium concentrations are lower, we could not detect any Ir anomally in the sample just above the S-interval.

A large number of quartz grains from the S-interval have been examined for the presence of shock lamellae. Because none of the grains show any such features, they are detrital in origin.

We may speculate on the origin of the spherule texture. For practical reasons, we distinguished three morphological types of spherules: predominantly perfect spheres with smooth walls, drop-shaped spheroids, and composite forms containing randomly spaced globular bodies, but because intermediate forms occur, there can be no doubt that they are essentially the same. The spherules show a wide range of diameters, and they all possess some sort of a dense "wall" and a highly variable internal structure (Plates 6-9). Despite this variable internal structure we think that the spherules were originally massive and most likely consisted of glass (or a crystalline silicate). The internal growth textures are mediated by microscopic surface fractures, which often extend down into the interior of the spherules (arrows in Plates 6-9). During the alteration phase, when the spherules were still presumably mostly glass, exchange of elements with seawater took place via these fissures. The microscopic and submicroscopic fissures increased the surface area in the spherules, accelerating cation exchange with seawater. Eventually, all glass was thus altered into Fe-rich smectite. It may be assumed that the differences in the internal configurations of the spherules are closely connected with the number, spacing, and extent of these microscopic fissures. The presence of dark, iron-rich inner boundaries on the irregularly crenulate spherule "walls," 


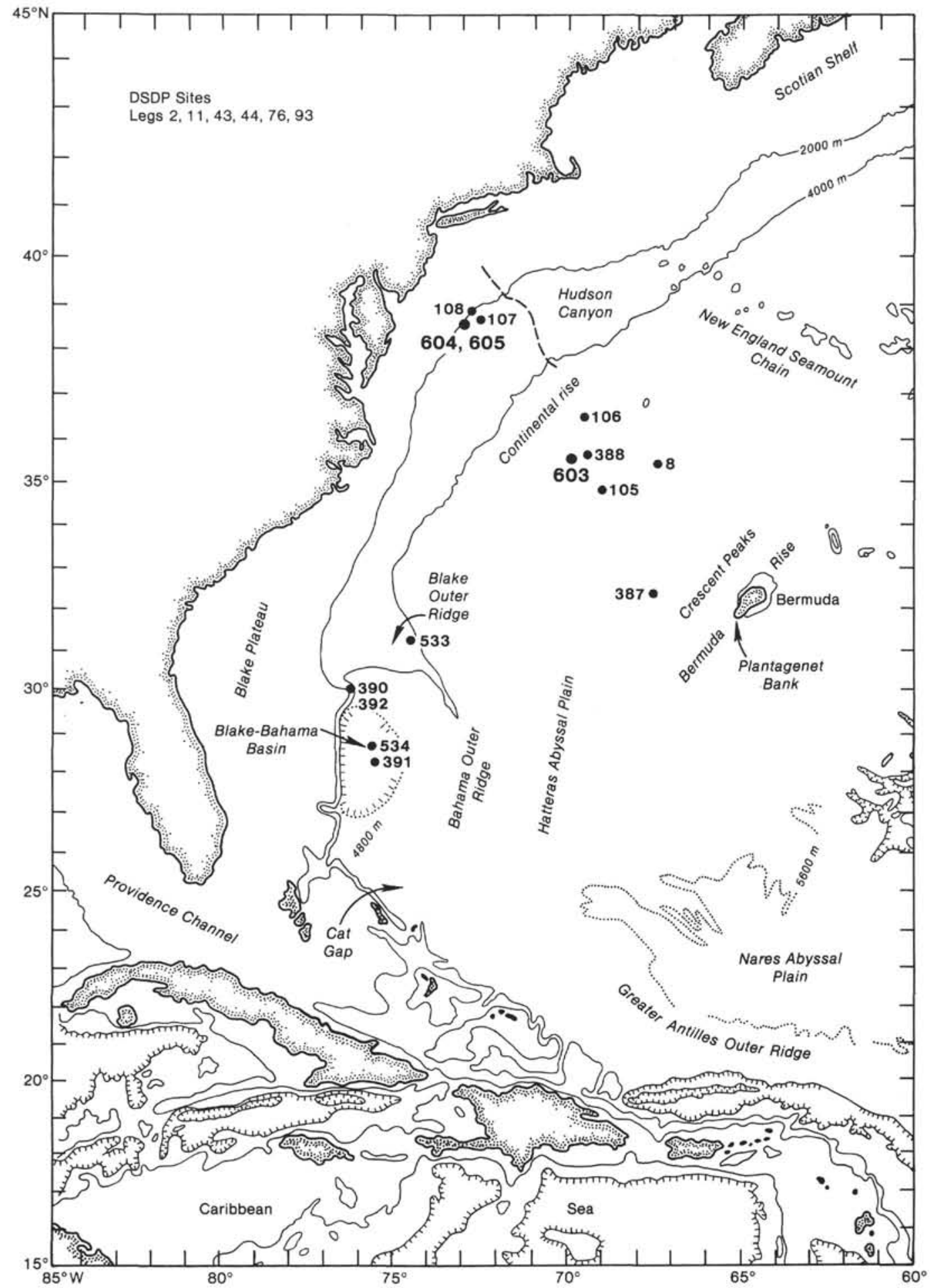

Figure 6. Physiographic features of the North American Basin and location of DSDP sites.

and of similar rims around the globules inside the spherules, may indicate that not all the available iron, from the former glass or from outside the spherules, was incorporated within the Fe-rich smectite.

In the model just discussed we propose that smectite directly replaced the original glass phase. However, we cannot exclude the hypothesis that the smectite actually represents a second stage of alteration, after initial alter- ation of the preceding glass phase into illite. The high $\mathrm{K}_{2} \mathrm{O}$ content of the smectite might then have been inherited from the illite. Whether or not smectite directly replaced the former glass, the presence of numerous fissures allowing seawater to come in contact with a large surface area, and thus facilitating the exchange of material, implies that smectite was formed in an open system. Thus, the major element composition of the spher- 
ules does not represent the major element chemistry of former glass.

In summary, the REE and $\mathrm{Ni}, \mathrm{Co}$, and As profiles support the correlation of the dark green spherules with the K/T smectite spherules of DSDP Hole 390B. Moreover, the elemental variation in the S-interval can be plausibly explained in terms of redistribution by a turbidite of the original $\mathrm{K} / \mathrm{T}$ boundary clay.

\section{ACKNOWLEDGMENTS}

We thank J. E. van Hinte, who originally spotted the spherules, for providing us the samples and $\mathrm{M}$. de Bruin and his staff at the IRI (Delft) for analytical facilities. Electron microprobe analyses were performed by W. J. Lustenhouwer at the electron microprobe laboratory of the Instituut voor Aardwetenschappen, Vrije Universiteit, Amsterdam, with financial and personnel support by Z.W.O.-W.A.C.O.M. (research group for analytical chemistry of minerals and rocks subsidized by the Netherlands Organization for the Advancement of Pure Research). H. A. van Egmond of the Vrije Universiteit, Amsterdam, provided the microprobe polished thin sections, L. Witte and C. M. Mulder-Blanken produced the SEM photos, J. Wiersma prepared the plates, and L. H. Gonggryp typed the various drafts of the manuscript. J. H. Baker, J. Smit, and C. J. Orth critically read and improved the manuscript. All are thanked for their support.

\section{REFERENCES}

Alvarez, L. W., Alvarez, W., Asaro, F., and Michel, H. V., 1980. Extraterrestrial cause for the Cretaceous-Tertiary extinction. Science, 208:1095-1108.

Bohor, B. F., Foord, E. E., Modreski, P. J., and Triplehorn, D. M., 1984. Mineralogic evidence for an impact event at the CretaceousTertiary boundary. Science, 224:867-869.

Bruin, M. de, 1983. Instrumental neutron activation analysis-a routine method [Ph. D. thesis]. Delftse Universitaire Pers.

Brumsack, H. J., 1980. Geochemistry of Cretaceous black shales from the Atlantic Ocean (DSDP Legs 11, 14, 36, and 41). Chem. Geol., 31:1-25.

Dean, W. A., and Gardner, J. V., 1982. Origin and geochemistry of redox cycles of Jurassic to Eocene Age, Cape Verde Basin (DSDP Site 367), continental margin of north-west Africa. In Schlanger, S. O., and Cita, M. B. (Eds.), Nature and Origin of Cretaceous Carbon-rich Facies: London (Academic Press), pp. 55-78.

Gaast, S. J. van der, and Vaars, A. J., 1981. A method to eliminate the background in X-ray diffraction patterns of oriented clay mineral samples. Clay. Miner., 16:383-393.

Haskin, L. A., and Paster, T. P., 1979. Geochemistry and mineralogy of the rare earths. In Gschneider, K. A., Jr., and Eyring, L. R. (Eds.), Handbook on the Physics and Chemistry of Rare Earths (Vol. 3): Amsterdam (North-Holland Publ. Co.), 1-80.
Kastner, M., Asaro, F., Michel, H. V., Alvarez, W., and Alvarez, L. W., 1984. The precursor of the Cretaceous-Tertiary boundary clays at Stevns Klint, Denmark, and DSDP Hole 465A. Science, 226: 137-143.

McLennan, S. M., Nance, W. B., and Taylor, S. R., 1980. Rare earth element-thorium correlations in sedimentary rocks, and the composition of the continental crust. Geochim. Cosmochim. Acta, 44: 1833-1839.

Montanari, A., Hay, R. L., Alvarez, W., Asaro, F., Michel, H. V., Alvarez, L. W., and Smit, J., 1983. Spheroids at the Cretaceous-Tertiary boundary are altered droplets of basaltic composition. Geology, 11:668-671.

Patchett, P. J., White, W. M., Feldmann, H., Kielinczuk, S., and Hofmann, A. W., 1984. Hafnium/rare earth element fractionation in the sedimentary system and crustal recycling into the Earth's mantle. Earth Plant. Sci. Lett., 69:365-378.

Piper, D. Z., 1974. Rare earth elements in the sedimentary cycle: a summary. Chem. Geol., 14:285-304.

Schmidt, R. R., 1978. Calcareous nannoplankton from the western North Atlantic, DSDP Leg 44. In Benson, W. E., Sheridan, R. E., et al. Init. Repts. DSDP, 44: Washington (U.S. Govt. Printing Office), 703-730.

Smit, J., 1984. Evidence for worldwide microtektite strewn field at the Cretaceous-Tertiary boundary. Geol. Soc. Am. Abstr. Progr., p. 659.

Smit, J., and Hertogen, J., 1980. an extra-terrestrial event at the Cretaceous-Tertiary boundary. Nature, 285:198-200.

Smit, J., and Klaver, G., 1981. Sanidine spherules at the CretaceousTertiary boundary indicate a large impact event. Nature, 292:4749.

Smit, J., and Kyte, F. T., 1984. Siderophile-rich magnetic spheroids from the Cretaceous-Tertiary boundary in Umbria, Italy. Nature, 310:403-405.

Smit, J., and Ten Kate, W. G. H. Z., 1982. Trace-element patterns at the Cretaceous-Tertiary boundary-consequences of a large impact. Cret. Res., 3:307-332.

Weaver, C. E., and Pollard, L. D., 1973, The Chemistry of Clay Minerals: Amsterdam, (Elsevier).

Weering, T. C. E. van, and Klaver, G. T., 1985. Trace element fractionation and distribution in turbidites, homogeneous and pelagic deposits; the Zaire Fan, southeast Atlantic Ocean. Geo-Mar. Lett., 5:165-170.

\section{Date of Initial Receipt: 27 March 1985}

Date of Acceptance: 18 February 1986

\section{APPENDIX}

Natural remanent magnetization (NRM) was measured on 10 samples close to the spherule bed of Core 603B-22 (see Bruins et al. and Canninga et al., both this volume, for paleomagnetic methods). The results in Table 1 show that total NRM intensities are too low to expect that a reliable magnetostratigraphy could be established if a completely recovered section were available.

Table 1. Initial total NRM intensities and directions of 10 samples from Cores 603B-18 to -22 .

\begin{tabular}{lrrrrrrrr}
\hline $\begin{array}{c}\text { Core-Section } \\
\text { (interval in cm) }\end{array}$ & $\mathrm{A}(\mu \mathrm{A} / \mathrm{m})$ & $\mathrm{B}(\mu \mathrm{A} / \mathrm{m})$ & $\mathrm{C}(\mu \mathrm{A} / \mathrm{m})$ & Dec. $\left(^{\circ}\right)$ & Inc. $\left({ }^{\circ}\right)$ & $\mathrm{R}(\mu \mathrm{A} / \mathrm{m})$ & Error & Range \\
\hline $18-1,103 / 1$ & -115.8 & -1390.5 & -108.1 & 355.55 & 4.75 & 1399.6 & 0.5 & 1 \\
$18-2,41$ & -157.0 & -32.5 & -60.2 & 298.43 & 66.43 & 171.4 & 2.4 & 1 \\
$20-1,18$ & 15483.5 & -7174.4 & 12240.6 & 59.62 & -47.49 & 21001.0 & 1.2 & 10 \\
$20-3,106$ & -382.9 & -215.2 & 103.1 & 25.58 & 58.07 & 451.3 & 0.8 & 1 \\
$21-1,112$ & -61.9 & 125.7 & 99.3 & 141.70 & 21.16 & 171.8 & 2.2 & 1 \\
$21-2,37$ & -159.8 & -49.4 & 30.3 & 31.45 & 70.04 & 170.1 & 1.9 & 1 \\
$21-3,34$ & -98.9 & 49.9 & -95.3 & 297.66 & 42.58 & 146.3 & 3.6 & 1 \\
$21-5,37$ & -93.9 & -151.3 & -188.4 & 308.78 & 21.24 & 259.4 & 3.2 & 1 \\
$21-4,78$ & -60.2 & -36.4 & -80.7 & 294.34 & 34.24 & 107.2 & 4.3 & 1 \\
$22-2$ & -78.1 & 84.1 & -85.2 & 225.40 & 33.15 & 143.1 & 3.5 & 1 \\
\hline
\end{tabular}



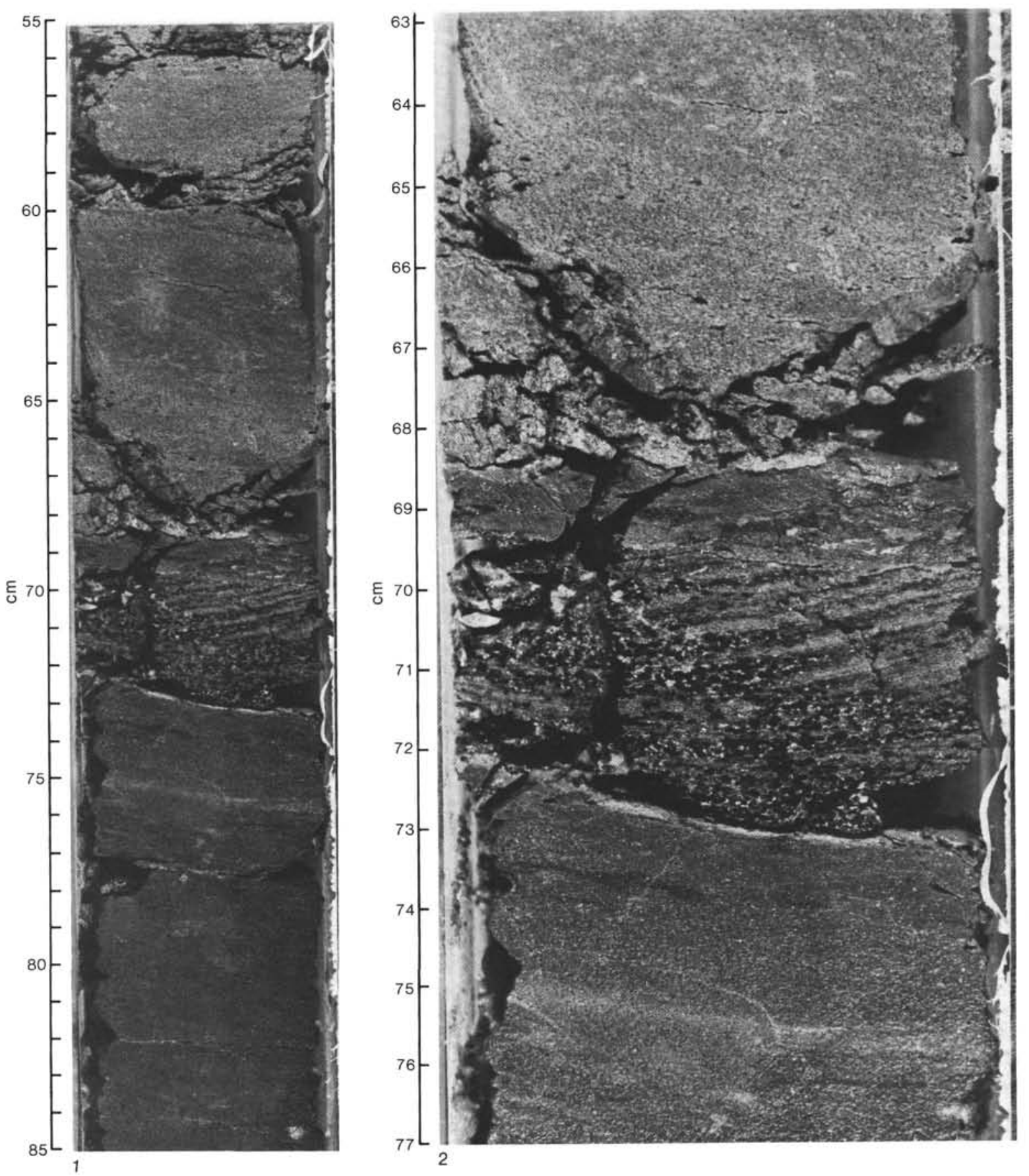

Plate 1. Section 603B-22-3. 1. Section 3 between 55 and $85 \mathrm{~cm}$, showing cross-bedded and parallel-laminated interval at $68-73 \mathrm{~cm}$. 2. Detail of cross-bedded and parallel-laminated interval. 


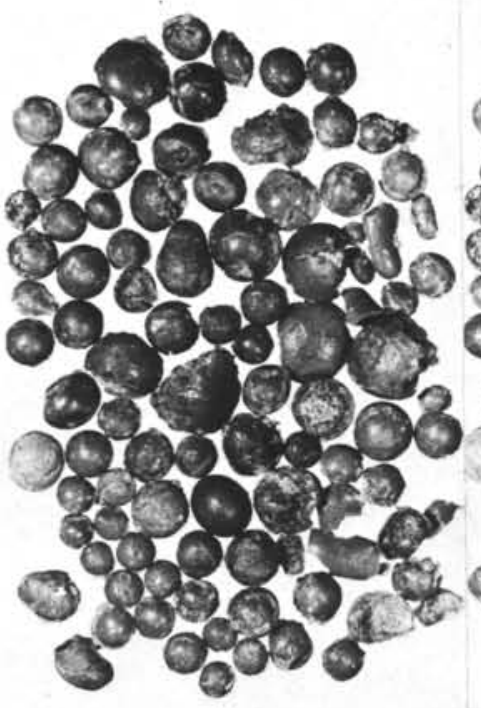

$1 \mathrm{~mm}$

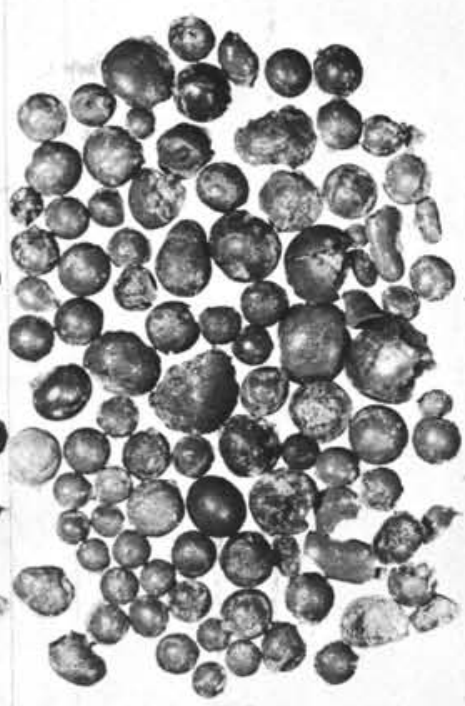

1
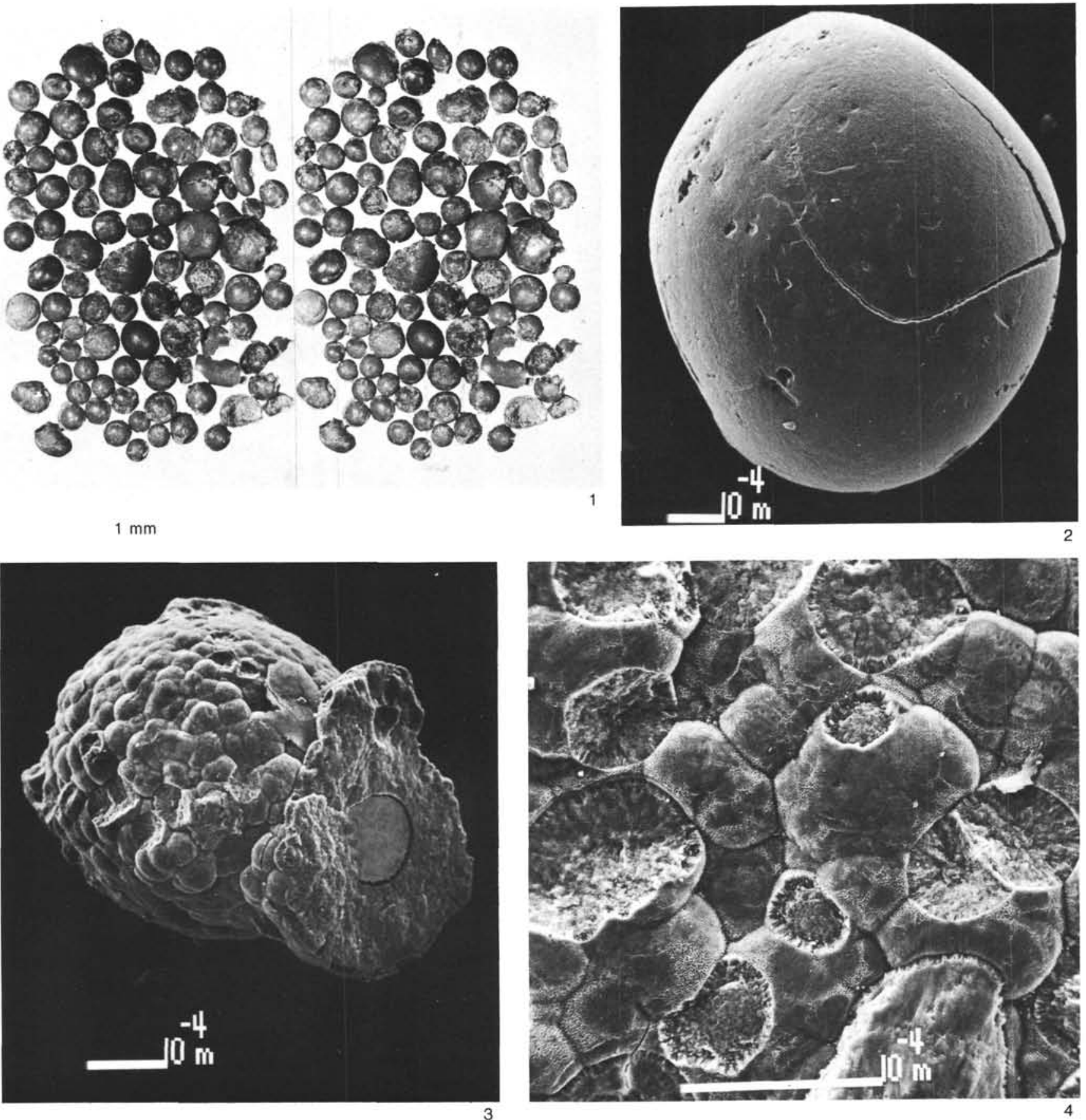

Plate 2. Fe-rich smectite spherules from a sample from Section 603B-22-3. 1. Stereopair of spherules showing their smooth outer skin. Only a few are elongate or drop-shaped, or have an irregular form. Bottom right are some fragments of hollow spherules. 2. View of the surface of a smooth spherule (SEM). 3. Atypical spherule with a lumpy surface. 4. Enlarged detail of surface of spherule in Fig. 3 (location not shown in Fig. 3). 

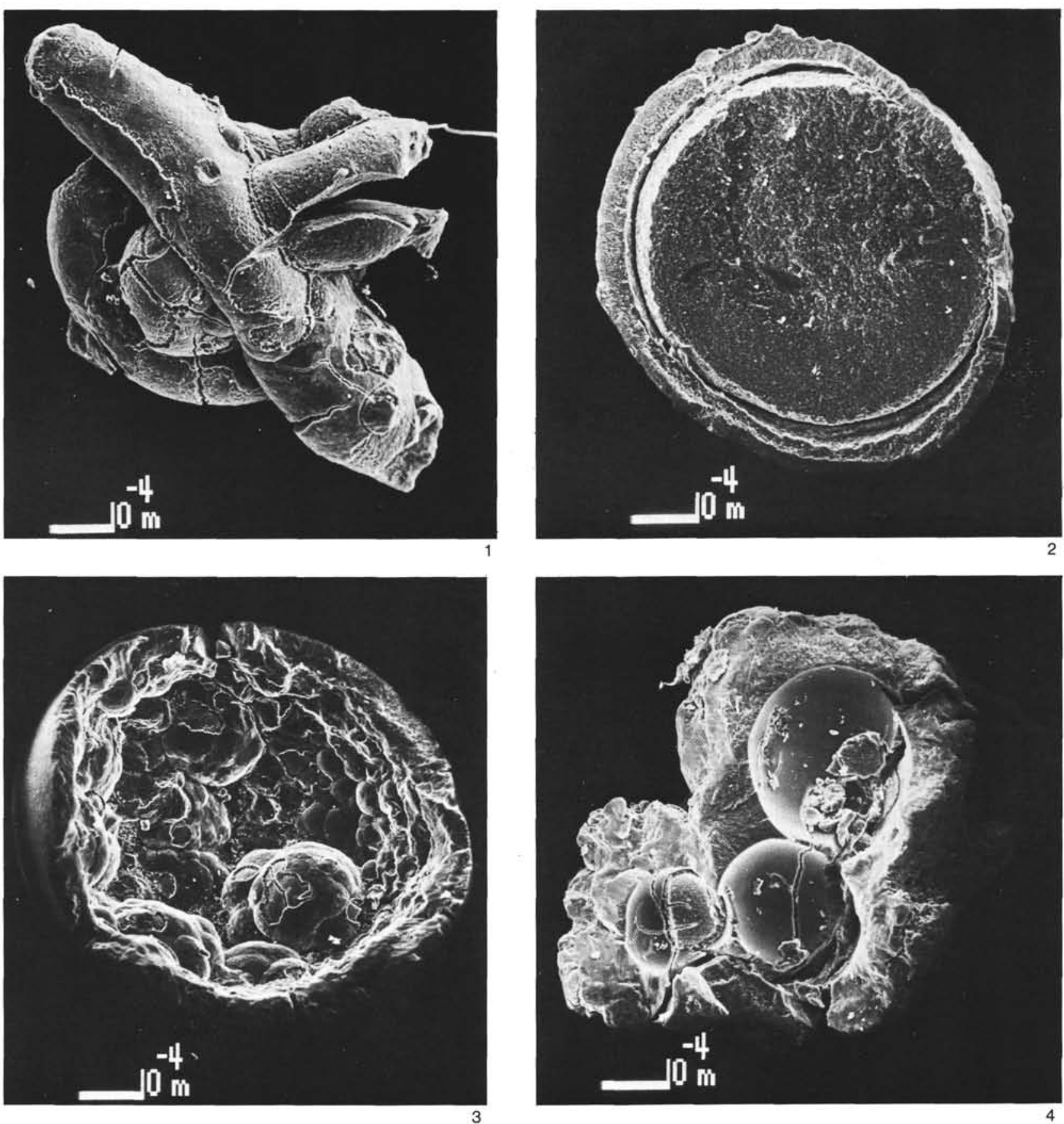

Plate 3. Fe-rich smectite spherules from Section 603B-22-3. 1. SEM micrograph of a concretion-shaped particle; cracks are artifacts of SEM preparation. 2. SEM micrograph of a cross-sectioned spherule showing a homogeneous interior mass which, probably because of shrinkage, became largely detached from a massive wall. 3. SEM view of the nodular inner side of a hollow spherule. 4. Portion of a composite type of spherule with three closely spaced molds from globular bodies; note small pieces of the walls of the globules still adhering to the molds. 

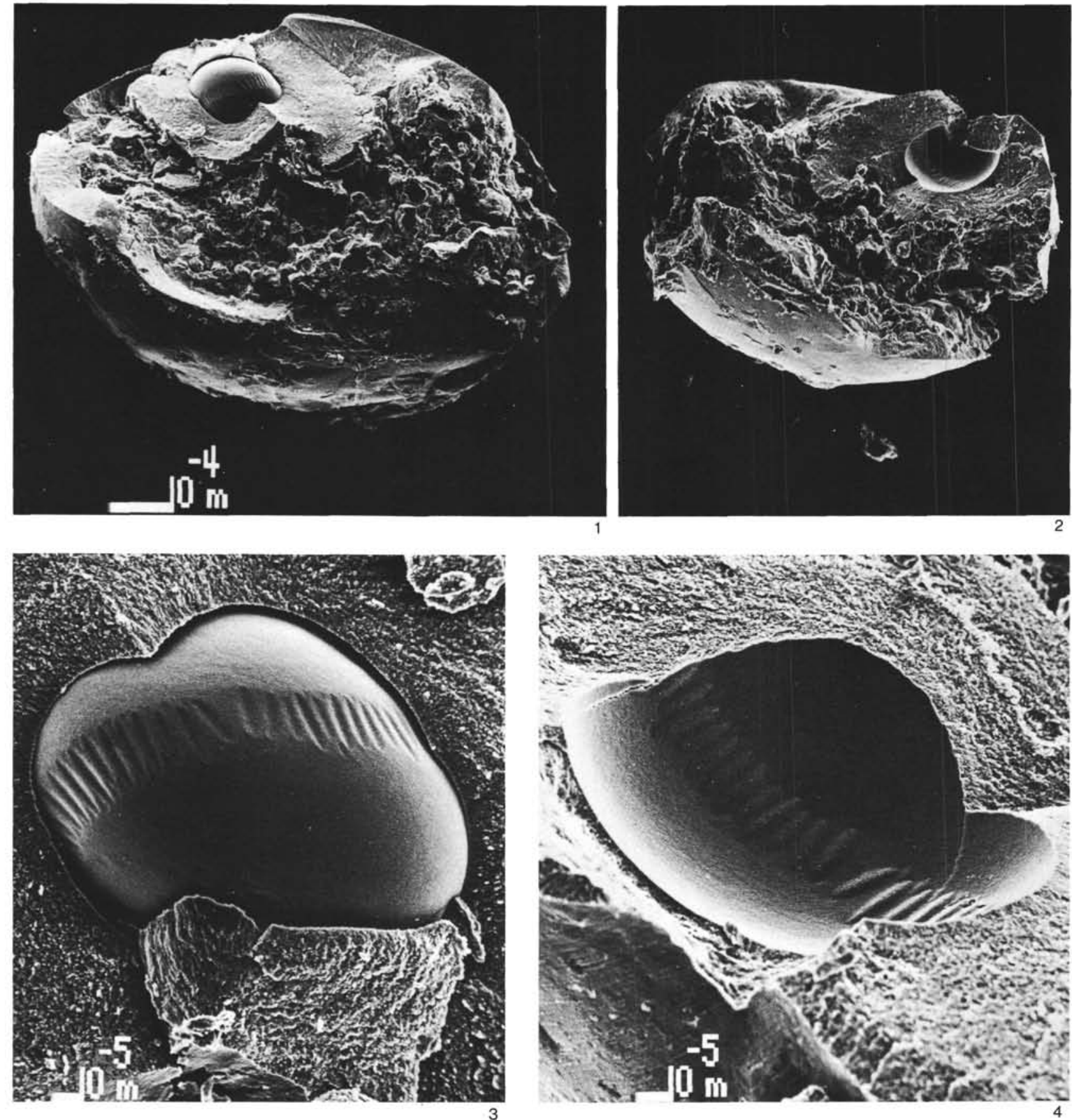

Plate 4. Fe-rich smectite spherule from Section 603B-22-3. 1, 2. SEM micrographs of counter halves of a cross-sectioned spherule; shown are (1) the fractured surfaces with the embedded globule still present, and (2) its mold. 3, 4. Both globule and mold are shown in more detail in order to bring out a band-shaped pattern of juxtaposed fusiform impressions (3) that fits the positive counterpart inside the mold (4) (SEM). 

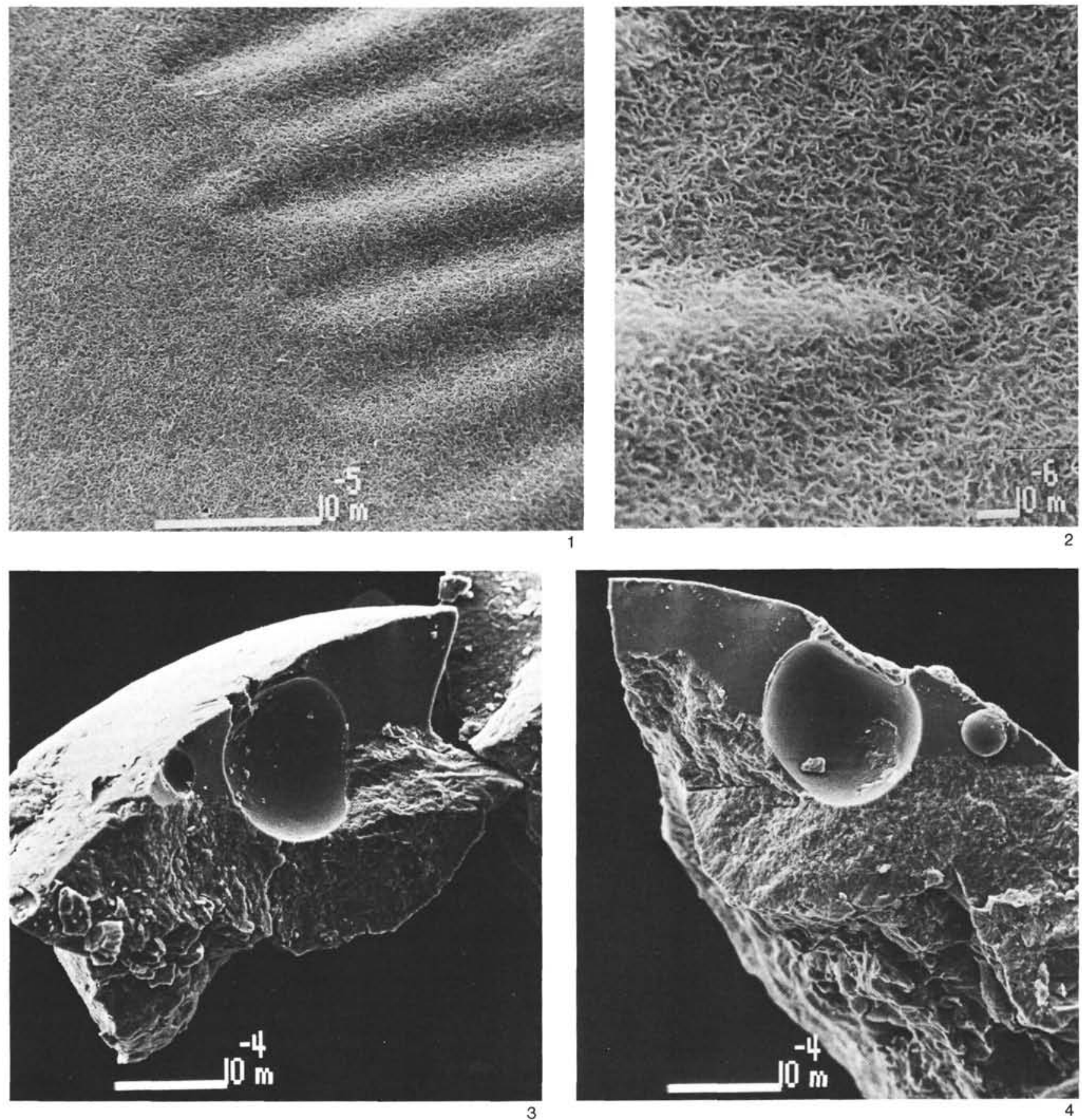

Plate 5. Fe-rich smectite spherules from Section 603B-22-3. 1, 2. Higher-resolution SEM micrographs of a small portion of the same globule and mold shown in Plate 4, Figs. 1-4. (1) Texture of the surface of the globule in situ of some fusiform impressions; (2) the same in counter relief for the mold that represents the embedding matrix. Note that the textures of the groundmass of globule and mold are identical and show no trace of deformation. 3, 4. Fragment of another cut spherule presenting the corresponding halves of two different-sized molds of globules that became embedded just beneath the spherule's surface. Fig. 4 shows the smaller mold with its globule still in position. The larger globule has been lost; notice that the smooth surface inside the mold is locally damaged, where the globule apparently adhered more firmly. 

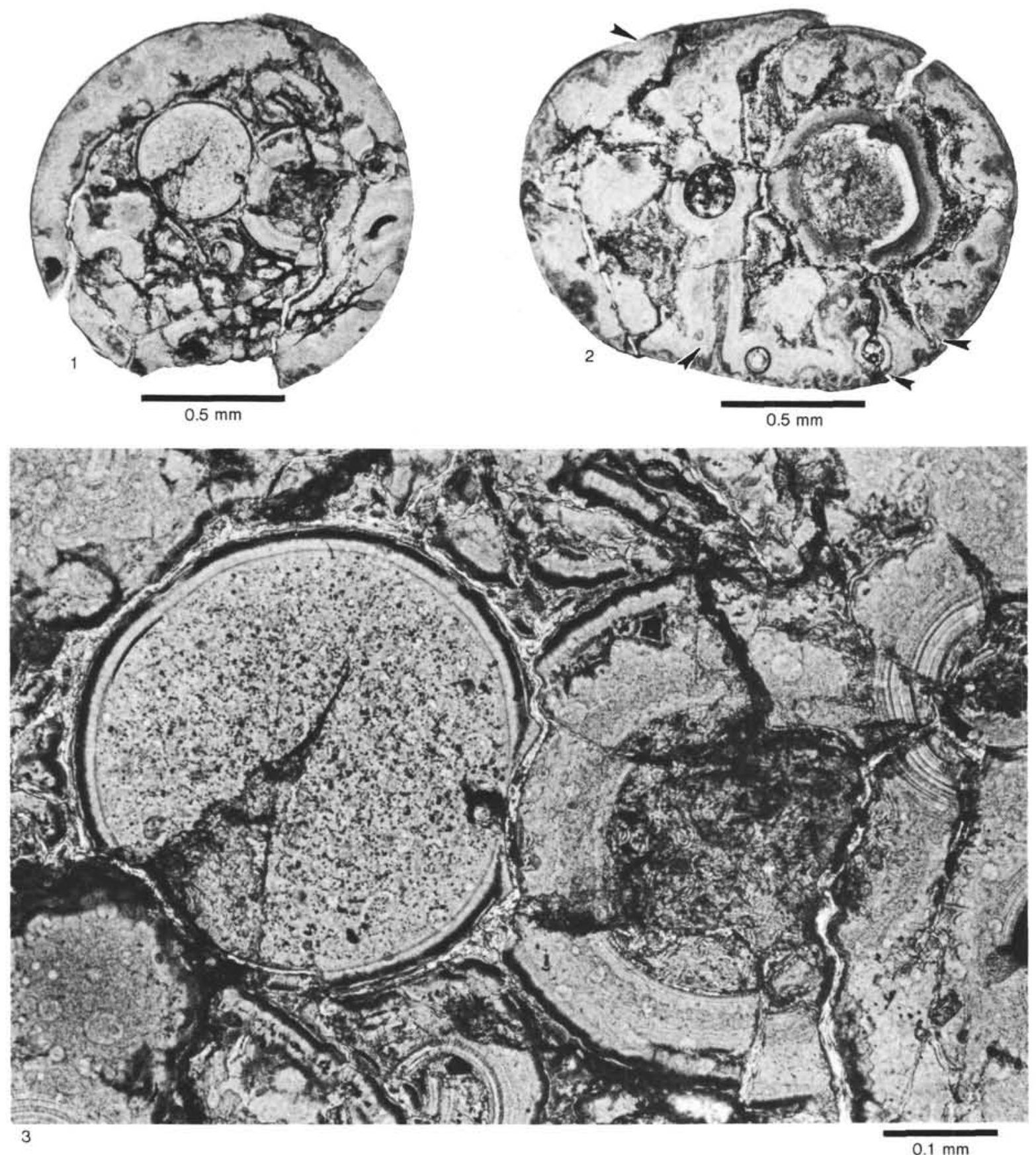

Plate 6. Fe-rich smectite spherules from Section 603B-22-3. 1, 2. Thin sections of two spherules seen in transmitted light. Note complex interior with randomly spaced, circular bodies identical to the globules in the scanning electron micrographs, exhibiting a wide range of dimensions. Arrows point to narrow surficial fissures through which altering fluid has penetrated. 3. Enlarged detail of specimen in Fig. 1. Light circular specks are from small blebs in the mounting medium. 


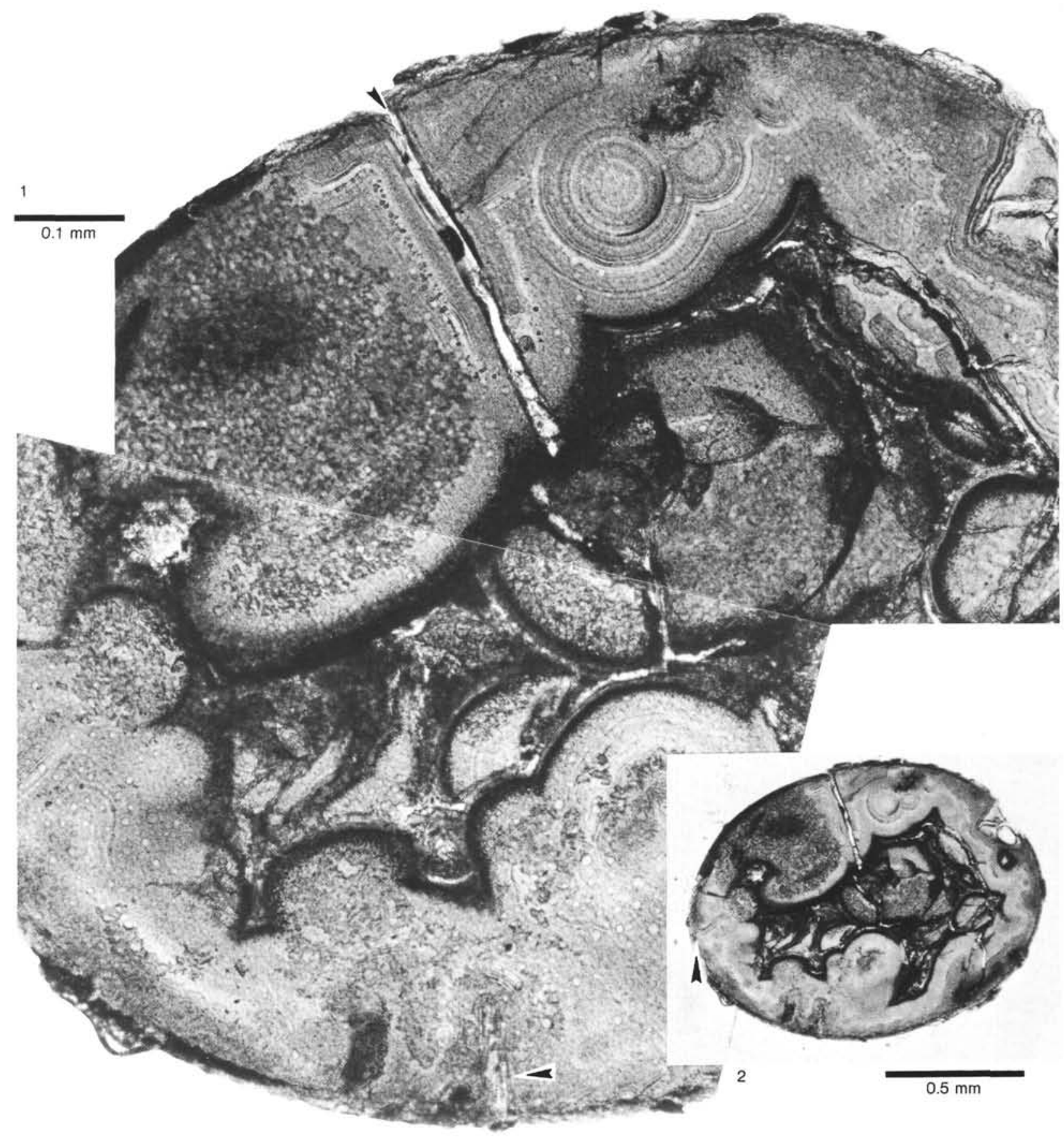

Plate 7. Fe-rich smectite spherule from Section 603B-22-3. 1. Thin section in transmitted light; shown is an enlarged portion of the spherule presented in full outline in Fig. 2. A massive nodular "wall" encloses an irregularly bounded central void. Black contours are from concentrations of an iron-rich substance. Arrows point to narrow fissures of different length and width (see text). Light circular speckling is from blebs in the mounting medium of the thin-section. 

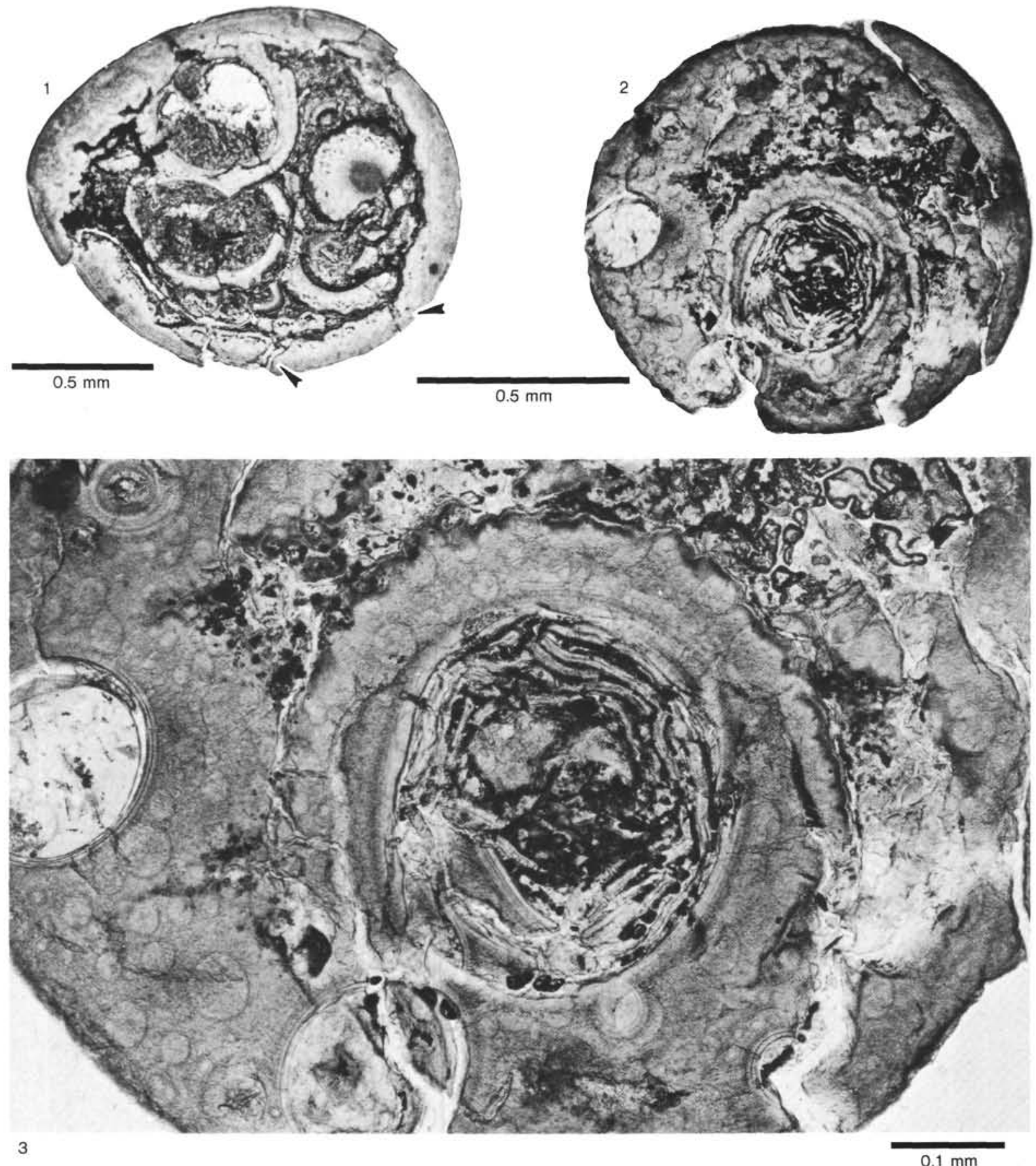

Plate 8. Fe-rich smectite spherules from Section 603B-22-3. 1. Thin sections of two spherules seen in transmitted light. Fig. 3 is an enlarged detail of Fig. 2. Smaller light-grey circles are from blebs in the mounting medium. 

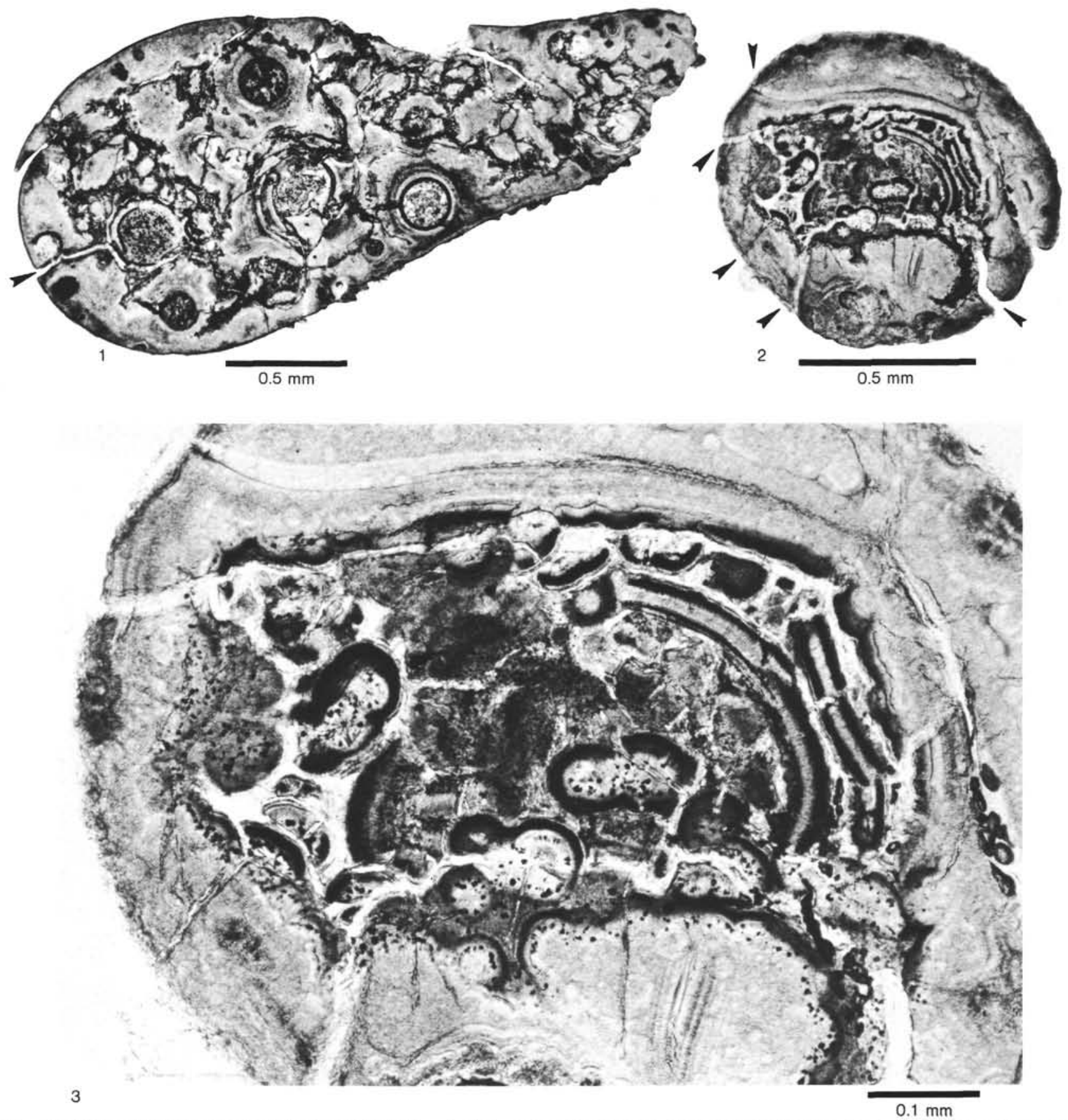

Plate 9. Fe-rich smectite spherules from Section 603B-22-3. 1. Thin section of a massive, drop-shaped spherule with several haphazardly spaced globular bodies showing a wide range of diameters. Arrow points to a conspicuous fissure leading to a globule that served as an inlet for the altering fluid. 2. Spherule with an inhomogeneously structured central void (enlarged view Fig. 3). Black margins are from a substance rich in iron. Arrows point to several comparatively large cracks that allowed altering fluid to penetrate into the central void. Light circular specks are from blebs in the mounting medium. 